\title{
Translation of Shanta Kumar's Lajjo as an Antidote to the Noxious Excesses of Postcolonial Writings
}

\section{SUMAN SHARMA}

"I will have to write my English after all - and how soon we forget it-is an Indo-Aryan tongue. Thus to stretch the English idiom to suit my needs seemed heroic enough for my urgent most demands. The Irish, remember, have done it (...) so why not Sanskrit (or if you will, be Indian) English?"

\section{Abstract}

-Raja Rao

By explaining the source culture for international audiences in their creations, the postcolonial writers not only recognize the superiority of English, they also betray their native audiences. In spite of the best efforts by these writers, their writings construct the native identities from a Eurocentric perspective. Regional literatures on the contrary, emerge out from an altogether different position. Hence, these literatures have the power to challenge the dominance of colonial as well as postcolonial writings. The translation of such native literature into the metropolitan language, significantly alters the syntactic and semantic fields of the target language. Shanta Kumar's Lajjo, is a Pahari Hindi text and is representative of contemporary regional life. This paper will explore as to how the translation of this text into English, had resulted in lessening the linguistic violence exhibited by the postcolonial writings. In addition, this paper will also discuss the possibility of new variety of inflected English, sprouting out of this translation.

Keywords: Postcolonial, Violence, Regional, Language, Culture, Erasure, Inflection.

These are the words in which one of the three pillars of modern Indian English fiction, advocated 'Sanskritic' version of English (Singh 2012: 40). The need for this approach possibly arose, when Indian authors realised that English language is insufficient in bringing out fully, the social cultural 
sensibilities of the native populace. The linguistic interference from Sanskrit and other Indian languages was the most expected outcome of British invasion of India. This interference may have begun, when the first English man set his feet on the Indian soil. With India remaining under the British subjugation for more than a century, it was natural for the Indian languages to interfere with the Standard English at various levels. To maintain a clear distinction between the ruler and the ruled, colonial literature was marked by assigning "stereotypical" identities to the Indian characters. These characters were often carved out to "exhibit" only those qualities which suited their subordinate position in colonial hierarchy (Kaul 2015: 2). After India (and other colonies too) gained independence, the post-colonial writers tried to create alternative identities for the native people. They also started a vigorous campaign to denounce colonial literature, but ultimately this endeavour ended on a sad note. By choosing to write in language of colonizers, these authors consciously or unconsciously recognized the superiority of their erstwhile colonial masters. The main reason for acceptance of this subservient position was, as Harish Trivedi (2013: vi) notes:

Indeed, the . . . that while all translation by definition bilingual, nearly all postcolonial writing by definition monolingual, for in a conspiracy of colonial complicity, it has been agreed that only that body of writing from the former colonies will be regarded as postcolonial which is written in the language of formal colonizers.

Thus, literatures written in regional languages were conveniently ignored, as they were not of colonizer's taste. Moreover, such a literature could have also posed a serious threat to the foundations of colonial legacy. A considerable span of time has elapsed, since the postcolonial (PC) writers began challenging the prejudicial portrayal of indigenous 
people in colonial literature. Their efforts however, were doomed to fail, as they chose to ignore, rather betray their own language, people and culture. Actually, the success of their work depended not on the people about whom they write, but upon the kind of critical acclamation, they received from the western audiences. Due to various reasons, these writers are under constant pressure to conform to the expectation and belief of the west. So, rather than challenging and resisting the distorted identities created by colonial writers, the postcolonial writers are unwittingly "slinking back" to their erstwhile colonial masters "to be taken under their linguistic and cultural wings again" (Trivedi 2013: vi).

As a master creator of the fictional world, the PC writers have infinite number of the choices in transposing a part of "metatext of culture" into the metropolitan language. (21). A lot of factors influence the final constituents of a text written by such authors from marginalized cultures. In the beginning of their career (when they live the life of obscurity), they foreground the unfamiliar information from the source culture, in a bid to reach out to the international audiences. By doing so, the PC writers compromise on the literary quality of their text, because such information load, take considerable space in their novels. After gaining international acclaim, most of these authors chose to live abroad and enjoy "international patronage", which is fraught with risk of, comprising with "the form, content and perspective of the post-colonial works themselves" (31). It is only in some exceptional cases that such successful authors would dare to make "demands" on the international audiences (29). In addition, by concealing the debt they owe to the source culture, many of PC authors may have indulged in literary dishonesty by claiming that, "innovative elements of a specific text" created by them (35). 
The translation on the other hand, has a fixed text to transpose. Even when the translator has to explain the "implicit information" of the source culture such as, "Customs, beliefs and myth", the choice is limited by the fixed source text (26). In addition, the translator has a "greater range of paratextual commentary" (22) through which $\mathrm{S} / \mathrm{He}$ can explain the "presupposed" elements inherent in the source text (26). The alteration, inflection, or the domestication of the metropolitan language is comparatively higher in translations then the original texts written by PC authors. The reason for this unique "lexical texture" of translations is that there are number of socio-cultural lexical items in the source, for which there is no equivalent in the target language (25). Thus, both at linguistic and cultural levels, the translations have the greater chances in communicating with any metropolitan language, on equal footings.

Today, the discourse on postcolonial criticism has reached a peculiar stage. Many PC writers have realised their folly in writing in English. These writers, after leaving their mother language went over to write in their aunt's language (in metaphoric sense, refer to English). Though the mother may be poor and aunt rich and one has decided to go to rich aunt, one always aspires to write about one's mother. Saddened perhaps by the, "the drama of colony and colonizer - or of author and cultural establishment - being played out for arbitration on an American stage" the well-known African author, decided to return to write in his native language Gikuyu. He also "painfully" realised that the Kenyan subjects of his novels will never able to read their own struggle, "against colonial oppression" as portrayed by him (Tymoczko 1999, 32). He not only stopped here, but translated most of his novel written in Gikuyu in English himself. This is a welcome step and is a living proof that translation of regional literature is an effective 
mean to respond to the negative overtures of postcolonial writings.

Amitabh Gosh is recognized as a major postcolonial writer in India. He has written a number of fictions set in the former colonies. In few such novels situated in India, he has exhibited a visible streak of sympathy with his marginalized characters, but has miserably failed in deciphering their inner world. If we examine the three main characters in the novel The Hungry Tide, we may get some more insight into the working of PC writings. Out of these three; one is Piyali Roy, who is an American of Indian descent, second is Kanai Dutta who is a native Bengali, settled in Delhi. As most of narrative focus on first two characters, the readers of this novel get wellacquainted with the life, thoughts, attitude and beliefs of both Piyali and Kanai. The third character named Fokir is an illiterate fisherman from Sundarbans. He is one of the most heroic characters in the novel, but the readers can only make wild guesses about his psychology. His silence is eloquent, but without any voice. Similarly, in Ghosh's another novel, The Sea of Poppies, the characters from the dominant class are more convincing than character like Kalu who belongs to relegated class. Thus, the people on the periphery remain voiceless in his novels, for the simple reason that he neither understands their life, nor their language. These lower class characters are not able to express themselves in Ghosh's novel, because of the simple reason that they cannot speak in English. Moreover, Ghosh does not depend upon people like Fokir and Kalu for his literary survival, so to give voice to them is least of his concern. Anyhow, his novels will only be read by English speaking audiences. Now let us imagine a scenario in which these characters are allowed to speak in their own language. Would the things in the novels, still remain the same, as they stand now? The question is worth pondering 
over, but one thing is certain that both of them would have vehemently challenged their slanted depiction by the novelist.

Sharan Kumar Limbale's The Outcaste is a translation of a Marathi novel titled Akkarmasi. The original text was written in the Mahar dialect of Marathi and was later on translated into English by Santosh Bhoomkar. The narrative of the novel is strikingly different than any of the postcolonial writers. For the present researcher, going through this novel was a cultural shock and at times he thought these narrations to be blatant exaggerations of the facts. There could have been multiple reasons for this disbelief, but some of them, as I understand could be; personality hybridization, neo-imperialism and may be postcolonial writings. Even after years, of gaining independence, we (the people from the former colonies) have not been able to come out of the inferiority complex induced in our personalities, during the colonial period. We have been westernized to such an extent, that we do not want to accept our past. At times, we tend to conveniently forget about the injustices and the miseries that once existed in our country. This loss of memory has also been reaffirmed by the postcolonial writers. However, the regional literature still remembers everything and when translated, has the power to jolt us out of our selective amnesia. In addition, such literature has the authority to dispel, the manipulation and erasure affected by the postcolonial writings. In fact, the native language is a powerful tool to preserve, maintain and recover our history.

The PC writers write native history by implying linguistic means of the colonizers. So, in the end, what the readers get to read is not the real history, but only its "distant echo" (Pierre 2013: 19). Kiran Nagarkar's The Cuckold is a historical fiction on medieval Rajasthan. The story is set in important period of history, when the Mughal empire in India, was in its nascent 
stage. By the time the kingdom of Mewar was ruled by the legendary Rana Sanga. The main characters of the novel however, are Bojhraj 'the prince of Mewar' and his wellknown saintly wife Meera Bai. The novel seems to be a partial translation of legend, lifestyle, culture, myth, folklore, history and the entire socio-cultural matrix of medieval Mewar. In this novel, the specific terms and expressions related to distinct, socio-cultural Mewari space of the time is conveniently replaced with the equivalent English space. For example, the word 'office' was used for the room, where the prince used to hold discussion with his officials. This room or hall might have the particular word to represent it in the Rajasthani or any of its dialect. Nagarkar by choosing to retain the English word office in this novel had unconsciously indulged in linguistic "violence" (St-Pierre 1993: 16). Similarly, other English words like colour and cuffs, small causes court, deputy minister of home affairs, had replaced the equivalent lexical items of the bygone era. Even the present researcher, (who had the opportunity to study in reasonably good English medium school) struggled hard to comprehend English used in the novel. It seemed that the author has been dipped into the mystical English water for a considerable span of time, before he was allowed to pen this novel. Whatever may be the cause and reason of such stylistic, the loss has been enormous. This loss has been twofold: one at the level of meaning and another at the level of culture. It would be a great idea, if a full research, on this aspect of erasure in this novel or other such novel is conducted by the interested scholar. In the review of the novel The Cuckold in Goodreads webpage, a comment by a visitor warrants special mention. He writes, "It wastes 23 [Sic] pages actually. The setting is 16th century, and Nagarkar writes sentences like 'I think he got the drift ...'- 'Must have cost you an arm and a leg.'- 'He had a point there ...' I mean, Mr. Nagarkar, you can't even hint at slang when you're writing 
Historical Fiction in a foreign language. Know that" (Solanki 2013: n.d.).

To be ignorant of the standing of regional literature is one thing and to be utterly contemptuous is another. The inadvertent error of giving false identity can still be pardoned, but the deliberate derision of native literature cannot be ignored. In her scholarly article, Vedita Cowaloosurr (2013: 137-8) discusses the haughtiness of another major postcolonial writer Salman Rushdie, for the contempt he holds for the vernacular literature. On the occasion to mark the fifty years of Indian literature post-independence, Salman Rushdie indulged in derogatory comparison of the Indian writing in English visa-vis the Bhasha literature. Harish Trivedi draws an apt colonial imagery to bring out the attitudinal perversity of such writers: "For Rushdie and his ilk, a writer in the Indian languages is rather like Forster's punka-wallah, primitively named and mute and seated right outside the white bungalow in the hot and dusty verandah". To negate the importance of vernacular literature is to negate India as a multicultural and multilingual nation. This is indeed a sad situation and might have been the reason that led erudite translation studies scholar Harish Trivedi (2013: vii) to observe: "Thus contextualised, translation may even seem to be an antidote to the noxious excesses of the postcolonial [...]", part of which I have used as the title of this paper.

At best, the PC writers can act as mediator between the world they represent and the world they create and this could be problematic. This could be explained by citing an example. Pierre, in his previously mentioned article, quotes the reminiscences of Fakir Mohan Senapati (regarded as father of modern Odia literature). In these recollections, Senapati shares with the readers, some of the experiences he had as an interlanguage translator. He recounts that he was 
misunderstood, when he made a genuine correction in a translation from English into Odia. Some relevant portion of the paper has been reproduced for the benefits of readers of the present paper:

The Sahib was confident of his command of Odia. After struggling for many days, he translated a small English book into Odia. When the translation was done, it was decided that I should make any necessary corrections, after which Bhikari Bhai, the head of the missionaries, would read it through from beginning to end. If approved, it would be printed. On receiving the manuscript, I began to make corrections. As far as I can remember, the first sentence of the book read as follows [this is a back translation from the Odia]: "There are this kind of people in the world who do not believe in God in the world.' I corrected this to read, 'There are many people in the world who deny the existence ('astitwo') of God.' After making my corrections, I went to Bhikari Bhai with the book. He was not used to hand-written manuscripts, and so I read it out to him. After the first sentence, he became angry and shouted, 'What? What have you written, pundit? The 'bone' of God? Is God like some idol of idol-worshippers, made of wood and stone, that He can have bones?' I gaped at him in bewilderment. Bhikari Bhai was trying to convince me that God had no bones. I asked him in a quiet and polite tone, 'Bhikari Bhai! Where have I mentioned bones?' He replied, 'You have written: "People who deny the asthi of God." Don't we know that asthi means "bones"?' So saying, he went out to the Sahib and blind with rage shouted, 'Sahib brother! The pundit has defiled your work by mentioning unholy things.' To the Sahib, Bhikari Bhai was a learned person, as he could haltingly read the gospels according to John, Luke and Matthew in the printed Bible. Moreover, he was a Christian and therefore a person worthy of trust. What he was saying had to be true. I was an idol-worshipping evil Hindu and consequently should not be trusted. Without heeding my pleas, the Sahib started yelling at me. For a long time he 
would not talk to me properly. I never learned the fate of the manuscript he had authored (Pierre 2013: 9-10).

In another instance, Senapati as the Dewan of the princely state of Dompara deliberately mistranslated the naive peasants:

His body completely covered in an English blanket the Sahib came out and stood in front of his tent, with only his eyes and face visible. The bench clerk and I stood beside him. The Sahib asked in Hindi, 'Well, subjects! Do you agree that Phakir Mohan Babu, the Dewan, can act as mediator to settle your dispute with the King?' Four or five leading headmen cried out together, "Why have you bothered to come from Cuttack in the rain and the storm if the Dewan Babu is going to solve the problem?' Failing to make out what they were saying, the Sahib looked at me. I immediately told him, 'They're saying that when the Dewan Babu is present to settle the dispute, why are you putting yourself through pain and suffering by coming from Cuttack in such rainy weather?' The Sahib responded, 'Very good, very good! The Dewan Babu will do what is necessary. He's a competent man, and we trust him. Goodbye, subjects, goodbye!' Saying that, he hurried back into the tent and drew the curtain. The headmen looked at each other, wondering what had happened. What had the Sahib understood? The clerks were my friends and the orderlies my subordinates, and they drove the subjects away from the tent (Pierre 2013: 10-11).

The reason to reproduce such lengthy quotations here is to emphasize upon the power of translation, which even if twisted a little can entirely change the meaning of a text and may also lead to the confusion and mistrust.

With the opening of economy and ease of communication (through media and high-speed internet) the interaction among the people around the world has increased manifold. In the current situation, youth in India is being influenced more by the western idols, then with the native, "language, history, 
culture, sense of past, local practices of childhood, local realities and cultural values" (Pierre 2013, 20). This is why the desi version of dhoti clad Spiderman comic series failed to be a commercial success in India. Though it would be quite preposterous to denounce without distinction, all that the western culture and thought stands for, it is equally vital that the people from former colonies, guard themselves against mimicking the west. Few decades back, Kangra youngsters from the rural area found it embarrassing to communicate in Kangri, especially in formal gatherings of cosmopolitan character. On such occasions they would try hard to converse in Hindi. Even the most outstanding student of rural school would not dare to venture in the realm of English. My cousin, who was educated and resided in a remote village, found it quite hard to speak in Hindi, when she went to attend a marriage in Delhi. Here, her Pahari mixed with Hindi made her the butt of everyone's joke. Even now, the high-ranking officials, having roots in Kangra villages, and who are residing outside the state do not want to converse in Pahari. During his school days, present researcher got an opportunity to participate in a Hindi debate competition. Although, he secured second position in the said event, he was still not accepted in the group of so called English speaking intellectual students. In universities too, the people feel proud to converse in English or at least in Hindi. The authorities draw a strange linguistic power by conversing in hegemonic languages. This might have been one of the possible reasons, why some of the Pahari writers chose to write in Hindi.

Manoj Chayya (2012: 198) in his paper, "Translating Culture and 'Cultural Translation' in Jayant Khatri's Gujarati Short Stories" writes that Jayant Khatri a native of Kachh writes in Gujarati and hence, he is translating the Kacchi culture in Gujarati. So, to translate Khatri is like the second translation. 
Similarly, Shanta Kumar is a native of Kangra and language spoken in Kangra is Pahari. Between the 16th and 19th centuries the Takri script was used in writing the Pahari language which was gradually, "supplanted by Devanagari" (Script Source - Takri, Takri, Ṭākrī, Ṭānkkrī, n.d.). B N Goswamy (1966: 210) an eminent art historian, also confirm the use of Takri script in reference to a letter written by a painter to his royal patron. He writes, "The language used is a matter that calls for some discussion, but may roughly be styled as a version of Western Pahari; the script is a mixture apparently of Devasesha and Țākrı̄”. The old script of Pahari being replaced by Hindi, Shanta Kumar and his fellow Pahari writers were forced to write in Hindi. Hence, Shanta Kumar's Lajjo is a translation of the oral Pahari traditions into the Devnagri script. As a result of this translation, the Kangri sensibility, ideology and lifestyle have been expressed in a national language. This is not an ideal situation, as Hindi like English also acts as hegemonic language for the regional languages, like Pahari. The national language also has the same power of appropriation as the English, and has devoured the culture and the Pahari dialect itself.

Though Lajjo is written in Devnagri, the author had tried hard to come out of dominance of Hindi, by bringing out the sociiocultural aspects of Kangra in novel. Linguistically too, he had tried to depict the presence of Pahari in the text. At number of places in the novel, his characters converse in Pahari dialect. For example, immediately after her marriage Lajjo was instructed by the Badi Dadi regarding how to conduct herself in her new home:

-"लाड़िए, रोज भियागा उठी कर बत्ता दी पूजा करा कर / नौईई नूंह इक्की साले तिकर बत्ता दी पूजा जरूर कर दी |" (बहू, प्रतिदिन प्रातः उठकर रास्ते की पूजा किया कर। नई बहू एक साल तक रास्ते की पूजा अवस्य करती हे) (Kumar 2011:8)| 
The author instead of writing these instructions in Hindi, chose to write it in Pahari by the way of transliteration. Though immediately after such transliterations, he had explained the meaning of this Pahari dialect in Hindi. This simply means that the author had accepted the dominance of Hindi in lieu of cultural expansion of Pahari. In the second translation of Lajjo into English, the history seems to repeat itself. The translator (who incidentally is also the researcher of this paper) made a conscious decision to retain the Pahari dialect (wherever it had occurred in the source), though obviously, transliteration of this dialect was in English letters. The meaning of this dialogue was then explained in the English language. This is how the Badi Dadi's instruction reproduced in preceding lines was translated by the translator:

Badi Dadi tutored a number of rituals to Lajjo and addressed her finally, "Ladiye, roj bhayaga utthi kari batta di pooja kara kar. Noi nu iki sale tak batta di pooja jaroor kardi." (Dear daughter-in-law, you should worship the pathway every morning. It is imperative for the new bride to worship the pathway for a year)

Just as the author resisted the dominance of Hindi and tried to preserve the cultural and social specific terms of the Pahari dialect in the first translation, the present researcher too tried hard to resist the hegemony of English. The translator too had retained the culturally loaded words in the English translation. A Pahari word like andron is incorporated in the translation and its meaning is explained in the glossary as the first time a bride enters her in-law's home. Similarly, other words like chillam 'cup of the Huqqa', chulaha 'an earthen oven', binna 'a soft and round cuisine made up of dry leaves so that the pitcher does not sting the head' Janet 'marriage party', malunh 'a pit to prepare manure', oweri 'a dark cool room of traditional Kangra village', Owen 'drawing room', ghar gharat 
'public place', gara 'mud mortar', khad 'rivulet' which are used in everyday Kangri, have also been retained as such and their meaning is explained in the glossary. The decision to retain the local words of the source language was influenced by yet another consideration.

Rani Padmini of Chittore: A Historical Romance is a historical fiction written by Armald Webb. The tale of this legendary figure is most grotesquely Americanised and the readers (especially those who are aware of Rajput history, culture and traditions) are barely able to relate with the characters in the novel. These readers feel that something is missing in this historical novel, written by a native American. David Bellos (2012: 18) writes about the concept of 'foreignness' in a foreign text. This feel of foreignness, is what I guess was found wanting in the novel. Until and unless the target readers find something foreign in a translation, they are bound to feel uneasy. Bellos notes that in an unrelated language, this foreignness is achieved by "altering the natural word order of sentences in English". While in related languages this is done by leaving parts of sentences in original. Bellos further observes that there is a, "distinct educational and social purpose" for leaving the original in the text, which gives an opportunity to the readers of target language to learn, what they had not learned in the school (13).

The novel Lajjo is representative of socio-cultural life of the people in the Kangra villages. The author had tried to dwell deep into the beliefs, thoughts and the attitudes of characters in the novel. Through a tightly knitted plot, the author has raised his concern on contemporary issues, like; plight of young war widows, the discriminatory practices followed by the society, on the basis of caste, religion, gender and political affiliations. Beside these issues, the author has enthusiastically narrated the various cultural practices and rituals followed by the villagers 
like; the worship of pathways and natural entities like bawaris 'water fountains'. Here it would be appropriate to reproduce the translation of one such practice, that is undertaken at the time, when a new bride enters her in law's house for the first time in Kangra:

After her marriage, the ritual of andron was performed under the guidance of Badi Dadi. At that time, her palanquin was kept outside the house. The Purohitji calculated the auspicious time. Accordingly, all the women under the leadership of Badi Dadi had gathered. The bridegroom Pyar Chand was made to stand just behind the bride Lajjo. They all were enclosed within a thread. ${ }^{1}$ Some close relatives were with them. Singing songs, all women moved towards the main door of the house. ${ }^{2}$ Uttering incantations, and carrying a pitcher, the Purohit was leading them all. That is how Lajjo first entered her husband's house.

On preliminary examination, it is evident that the language of above translation is imbedded in the source culture. If a nonnative or even for that matter an English medium school educated Himachali reads this translation, s/he may find this the cultural information as a unique learning experience. Bemused by the cultural practices enumerated in this translation, an inquisitive reader may want to explore more. This would be like bringing the audience to source culture. So, the very translation of this novel may result into further expansion of cultural base of Kangra in English speaking world and even beyond, as there is every possibility, that this translation is further translated in other languages.

\footnotetext{
${ }^{1}$ On every auspicious occasion, all family members of a typical Kangra village enter their house in this manner.

2 There is specific marriage song for different occasions and rituals in a traditional Kangra marriage.
} 
Though translation has been described by the scholars as an activity of violent enterprise, especially when it is from regional language into what Mark Fettes calls the "metropolitan" language (18). This linguistic violence replaces the cultural identities of source culture with the abstract identities of target text. This replacement erases "what is specific to the source language and culture" (Pierre 1999: 16). The PC writings being monolingual activity, indulge in this violence to the extremes and this calls for healing of these excesses through contextualised translation. In multilingual country like India, English can play an important contribution in initiating a meaningful conversation among regional languages. In other words, English can act as a filter language in facilitating inter-language translations. Over the years and by the way of continuous interaction between English and the regional languages have given rise to various variants of English. These variants are region specific like Punjabi English, Delhi English, Haryanvi English, Bihari English and so on. These versions of inflected English contain the peculiarities of the places from where they had originated. These variants sometimes violate drastically, the syntactic structures of the Standard English, but accommodate the uniqueness of the region and language. This is necessity too, as foreign language is inefficient in bringing out the peculiarities of a specific culture. Shalini Mishra and Anjani Mishra (2016: 30) in their scholarly article give various reasons for this linguistic interference. They record that, apart from influence of mother tongue, the major reason for the interference was, "[...] when the second or the foreign language becomes handicap to present any cultural, regional, religious or traditional meaning or context of the first language or the mother tongue". Beside this necessity to accommodate the native lexis, the regional variants of English facilitate the dismantling of umbrella term in which the Indian English has 
been categorised till recently. So, the postcolonial translators have a positive role to play in reducing the perilous effects of postcolonial writings.

Though seen in pejorative sense, the translator too had indulged in dissemination of socio- cultural information in this translation. However, the level of such information has been minimized as the translator had encoded most of such information in paratextual space. This had resulted into minimization of informative elements in the text, thus preserving the literary essence of the source text. Though, acceptance of English hegemony had resulted into loss for Pahari, but translator has every reason to feel satisfied that by translating Lajjo, he had made best possible use of English and without succumbing to any guilt, which characterises the debate on "homographic and heterographic translations" (Mathew 2005: 158). If the linguists take up from here and closely examine the translation of Lajjo, they may find that Pahari idioms, expressions, and frequently code switching have indeed inflected the target language in multiple ways. If a number of Pahari-Hindi text like Lajjo, is translated, then there is strong possibility of Himachali version of English. This may enable the integration of English medium educated urbanized Himachalis with their cultural roots. It would be like, what Pierre's (2013: 23) calls: “. . . creation of new Gemeinschaft communities, local communities evolving out of shared direct experience of translation."

\section{References}

Bellos, DAVID. 2012. Fiction of the Foreign. Translation studies: Theories and Application. ed. by Sunil Sawant. New Delhi: Atlantic.

Cawalsoor, Vedita. 2013. Translating the Translated: Koi accha-sa Ladka as the Hindi Avatar of A Suitable Boy. Translation and Postcolonialities: Transactions across 
Languages and Cultures. ed. by Vijay Guttal and Suchitra Mathur, 137-54. New Delhi: Orient Blackswan.

Chayya, ManoJ. 2012. Translating Culture and 'Cultural Translation' in Jayant Khatri's Gujarati Short Stories. Translation Studies: Contemporary Perspectives on Postcolonial and Subaltern Translations, ed. by Piyush Raval, 198-204. New Delhi: Viva Books, 2012.

DESPANDE, SHASHI. 2013. Dimensions of Translation.

Translation and Postcolonialities: Transactions across Languages and Cultures. ed. by Vijay Guttal and Suchitra Mathur, 1-8. New Delhi: Orient BlackSwan.

Gautam, TотA R. 2013. Loss and Gain in Translation from Hindi to English: A Stylistic Study of Multiple English Translations of Premchand's Godaan and Nirmala. Shodhganga. 21 Apr. 2016. Online: http://hdl.handle.net/10603/11238.

KaUL, RANJANA. 2014. The Imaging of the Anglo-Indian Woman in Literature. Shodhganag, 2. 6-Mar-2014. Online: http://hdl.handle.net/10603/16944.

Kumar, Shanta. 2011. Lajjo. New Delhi: Bhartiya Prakashan Sansthan. References to the text are from this edition.

MATHEW, SAJI. 2005. From Regional into Pan-Indian: Towards a Heterographic Praxis for Postcolonial Translation. In Translation: Reflections, Refractions, Transformations, ed. by Paul St-Pierre and Prafulla C. Kar, 151-61. Delhi: Pencraft International.

Mishra, Shalini.; and ANJANI Mishra. 2016. Linguistic Interference from Hindi in Indian English. International Journal on Studies in English Language and Literature 4(1). 29-38. Feb.2016. Online: https://www.arcjournals.org/pdfs/ijsell/v4-i2/4.pdf. NAGARKAR, KiRAN. 2015. The Cuckold. Noida: Harper Collins. SingH, AMAR. 2012. Translation, Hybridity and Transcreation. Translation Studies: Theories and Application. ed. by Sunil Sawant, New Delhi: Atlantic. 
Suman Sharma

Solanki, TANuJ. 2013. Review of Cuckold. Goodreads. 21 Aug. 2013 Online: goodreads.com/book/show/109326.Cuckold.

St-Pierre, Paul. 2013. A Fine Balancing Act: Translation in (Post) Colonial Settings. Translation and Postcolonialities: Transactions across Languages and Cultures. ed. by Vijay Guttal and Suchitra Mathur. 137-51. New Delhi: Orient Blackswan.

TRIVEDI, HARISH. 2013. Foreword. Translation and Postcolonialities: Transactions across Languages and Cultures. ed. by Vijay Guttal and Suchitra Mathur, vii. New Delhi: Orient BlackSwan.

TYMOCZKO, MARIA. 1999. Post-colonial Writing and Literary Translation. Post-colonial Translation: Theory and Practice. ed. by Susan Basnett and Harish Trivedi, 19-40. London: Routledge.

Webb, Armald. 2006. Rani Padmini of Chittore: A Historical Romance. ed. by S K Bhatia, New Delhi: Gita Enterprises.

Goswamy, B. N. 1966. A painter's letter to his royal patron: An Old Tāânri document. Journal of the American oriental society. 86(2). 209-216. Jstor. Online: http://www.jstor.org/stable/596434.

Script Source - Takri, Ṭākrī, Tāñkrī. (n.d.). Retrieved from http://scriptsource.org/cms/scripts/page.php?item_id=script_d etail\&key=Takr 